\title{
Distinguishing entrepreneurial approaches to opportunity perception
}

\author{
Stern Neill, Lynn E. Metcalf and Jonathan L. York \\ Orfalea College of Business, California Polytechnic State University, \\ San Luis Obispo, California, USA
}

\begin{abstract}
Purpose - Whether opportunities are discovered or created by entrepreneurs is a foundational question in entrepreneurship research. The purpose of this paper is to examine women entrepreneurs in high-growth new ventures and explore the cognitive resources that distinguish between three approaches to opportunity perception: opportunity discovery; opportunity creation; and a combined discover-create (ambidextrous) approach.

Design/methodology/approach - Using questionnaire responses from 165 women entrepreneurs in highgrowth new ventures, K-means clustering was used to determine three approaches to opportunity perception. The cognitive resources associated with each approach were then identified using multiple discriminant analysis. Finally, multivariate analysis of variance was conducted to examine the relationship between opportunity perception and growth expectations.

Findings - These results demonstrate different approaches to opportunity perception among entrepreneurs in high-growth new ventures, the cognitive resources that reinforce each approach, and the expected new venture growth outcomes.

Research limitations/implications - The findings offer insight on the cognitive origins of opportunity perception by empirically identifying distinct approaches to opportunity perception and the cognitive resources that underlie each. The study relies on a unique sample of entrepreneurs to understand complex cognitive phenomenon.

Practical implications - Understanding the effects that cognitive factors have on opportunity perception provides direction for current and aspiring entrepreneurs. The findings and instrument may be used for professional development and to inform educational strategies.

Originality/value - The findings offer important contributions to entrepreneurial theory and practice by addressing repeated calls for research that examines the cognitive antecedents enabling opportunity formation (discovery, creation or both). This manuscript empirically does so, while opening up possibilities for future research.
\end{abstract}

Keywords Women entrepreneurs, Cognition, Growth expectations, Opportunity perception

Paper type Research paper

\section{Introduction}

Proximal to the field of entrepreneurship is whether opportunities are discovered or created by entrepreneurs. Opportunity discovery assumes an alert entrepreneur, who sees what others miss, while opportunity creation assumes an entrepreneur who uses available resources and abilities to form opportunity. A key distinction between these two approaches is whether the entrepreneur perceives the opportunity to be exogenous or endogenous. With discovery, opportunity is exogenous and forms through shifts in market conditions that the "alert" entrepreneur detects and exploits (Shane and Venkataraman, 2000). With create, opportunity is endogenous and forms through the actions of the entrepreneur, who brings opportunity into being (Baker and Nelson, 2005; Sarasvathy, 2001). Recent work (Alvarez et al., 2013) suggests the possibility of simultaneously engaging in discovery and creation, which requires the entrepreneur not only to see things that others miss but also to interact with the market, to iterate, and to engage in intuitive decision-making.

A question that arises is whether entrepreneurs who discover opportunity think and reason differently from entrepreneurs who create opportunity, as well as from ambidextrous entrepreneurs who simultaneously discover and create opportunity. Researchers have begun to 
operationalize the distinctive approaches that entrepreneurs take in exploiting opportunities (Chandler et al., 2011; Dew et al., 2009; Dutta and Thornhill, 2014; Fisher, 2012); however, the antecedent conditions to the chosen approach (i.e. discovery, creation or both) remains unexplored. While prior research examines how entrepreneurs might differ (e.g. Begley, 1995; Busenitz and Barney, 1997; Chen et al., 1998; Miner and Raju, 2004; Stewart and Roth, 2001) or benefit (cf. Grégoire et al., 2011) from various cognitive resources, this study extends this body of work by examining the cognitive resources that distinguish between each perspective.

While theoretically significant, the study of opportunity presents an empirical challenge (Dimov, 2011). Given that opportunity is an unobservable and empirically elusive phenomenon, Welter and Alvarez (2015) recommend examining the nature of the entrepreneur as a means of empirically testing opportunity types, which the authors suggest would move the literature from a solely theoretical to an empirical foundation. As noted above, opportunity discovery and opportunity creation reflect different approaches to opportunity perception. Unresolved is whether individual entrepreneurs may also perceive opportunity through both approaches - opportunity discovery and opportunity creation. This study explores these issues by addressing three research questions:

$R Q 1$. What is the tendency for entrepreneurs in high-growth new ventures to engage in one, the other, or both approaches to opportunity perception?

RQ2. How do cognitive (psychological) resources of entrepreneurs distinguish those who tend to rely on a discovery, creative, or ambidextrous approach to opportunity perception?

RQ3. How does the entrepreneur's approach to opportunity perception influence new venture growth expectations?

These research questions are examined within the context of an understudied population women who have founded high-growth new ventures. This context is particularly important for two reasons. First, while the body of entrepreneurship literature has grown substantially over the past decade, less is known about women entrepreneurs (Ahl and Nelson, 2010; Greene et al., 2003). As Jennings and Brush (2013, p. 698) point out, "the proportion of women's entrepreneurship research published within top-tier journals has steadily declined since the mid-1990s." These authors challenge researchers to expand knowledge of women entrepreneurs by investigating subpopulations and to examine issues around opportunity recognition, emotions and social entrepreneurship. Second, while research indicates that men and women cite similar motivations for starting a business (Cohoon et al., 2010), women are underrepresented among the overall population of entrepreneurs (Mitchell, 2011; Coleman and Robb, 2009; Shane, 2008). In the USA, women are half as likely as men to become entrepreneurs (Kauffman Foundation, 2016). Worldwide, women are less likely to report entrepreneurial intentions and to participate in entrepreneurship. A study on women's entrepreneurship in 83 countries reported lower female intentions to start businesses across all regions, as well as lower female participation in total early stage entrepreneurship across all regions (Kelly et al., 2015). With that said, some women do found high-growth businesses (Gundry and Welsch, 2001; Morris et al., 2006). This study seeks to build on the understanding of female founders of high-growth new ventures.

The study reported here offers a significant contribution to the literature by empirically examining approaches to opportunity perception. In doing so, the paper identifies the cognitive resources that distinguish between approaches and the growth expectations that result. By focusing on women who found high-growth businesses, the study also provides insight into an understudied group, as well as an opportunity to discuss practical implications. The paper presents a conceptual framework, followed by a description of the measures and methods, and concludes with the results and a discussion of the implications. 


\section{How opportunities are perceived}

No matter the origin, "opportunities sojourn in the minds of aspiring entrepreneurs as venture ideas, propped by perceptions and beliefs [...]" (Dimov, 2011, p. 64). Prevailing schools of thought suggest that the origin of opportunity is either present in existing market structures or exists only because of entrepreneurial invention. Shane and Venkataraman (2000) argue that opportunity exists as an objective phenomenon that is not known to all individuals. Existing only when perceived by the individual, "[o]pportunity by definition is unknown until discovered" (Kaish and Gilad, 1991, p. 38). According to this discovery view of opportunity perception, certain individuals are more alert to shifts and see gaps based on an acute ability to scan and to search systematically for new information (e.g. Kirzner, 1973; Chandler et al., 2011; Tang et al., 2012). Entrepreneurs who discover opportunity tend to set out purposefully, to search systematically, to engage in analysis, and to exploit existing knowledge and resources (Chandler et al., 2011; Shepherd et al., 2007).

Another view is that entrepreneurs bring opportunities into being through a creative process that relies on the entrepreneur's efforts and actions (Sanz-Velasco, 2006; Sarasvathy et al., 2010; Dutta and Thornhill, 2014). In the create view of opportunity perception, opportunities form as imagined possibilities that take shape based upon enacted actions. The viability of newly formed ideas is likely to be uncertain, so the entrepreneur initiates transformative and sensemaking processes to create opportunity (Alvarez and Barney, 2007; Klein, 2008; Wood and McKinley, 2010; Shane, 2012). The entrepreneur experiments and changes direction on the basis of new information (Dyer et al., 2008) and through interactions with people in their networks (Fisher, 2012; Wood and McKinley, 2010). In this way, entrepreneurs engage in iterative learning (Sanz-Velasco, 2006; Mitchell et al., 2008) and form opportunities that could not have existed without their actions. In this case, entrepreneurs are an integral part of opportunity emergence as they invent what they believe to be viable by relying on a set of deep and diverse prior experiences (Alvarez et al., 2013), as well as an extended network of resources and people (Dyer et al., 2009; Wood and McKinley, 2010).

As noted above, the literature also suggests that opportunity can be both discovered and created (Leyden and Link, 2015; Fisher, 2012; Sarasvathy, 2001) and that discovery and creation can form a virtuous and dynamic cycle, with context performing a discriminating role (Zahra, 2008). Leyden and Link (2015) theorize a two-step discovery-creation process, where entrepreneurs develop a social network and search for an innovation to pursue, and then use the social network to help bring the innovation into being. The work of Vaghely and Julien (2010) supports the notion that opportunity formation can result from simultaneous discovery and creation based on how the entrepreneur thinks and processes information. Based on a case study, they find that entrepreneurs rely on archived information and prior experience, as well as problem-solving and sensemaking and an ability to switch between modes of thinking.

The concept of ambidexterity is most often applied to the organization and its ability to engage simultaneously in competing strategies; e.g., flexible and efficient, explorative and exploitative, alignment and adaptability, search and stability, (cf. Simsek et al., 2009). Organizations achieve ambidexterity through structural or contextual mechanisms that allow the firm to cope with contradictory tensions (Gibson and Birkinshaw, 2004; Raisch and Birkinshaw, 2008). Firms that handle contradictory tensions through structural ambidexterity do so through separate units or subdivisions that specialize in different, possibly inconsistent, functions. For contextual ambidexterity, firms design systems and processes that support individual choice in allocating resources among competing demands. This has led to a duality in ambidexterity research, whereby researchers examine the organization's ability to navigate and channel contradiction either through structural differentiation or contextual integration (Raisch et al., 2009). 
While ambidextrous organizations realize superior performance (Gibson and Birkinshaw, 2004; He and Wong, 2004; Junni et al., 2013; Lubatkin et al., 2006), individuals are essential to organizational ambidexterity. For effective structural integration, individuals (e.g. senior executives) must integrate across differentiated units (Jansen et al., 2009), while contextual integration requires individuals (e.g. decision makers) to use company-sanctioned systems and processes to reconcile competing demands (Raisch et al., 2009). Therefore, it is the people within an organization who must have the capacity to manage conflicting goals, contradicting information and competing roles (Floyd and Lane, 2000; Gibson and Birkinshaw, 2004; Smith and Tushman, 2005). In applying the concept of ambidexterity to managers and entrepreneurs, prior research suggests that individuals are able to benefit the organization by operating in seemingly opposing ways (Mom et al., 2009; Raisch et al., 2009; Volery et al., 2015) and has established specific behavioral, structural and social traits associated with managerial ambidexterity (Birkinshaw and Gibson, 2004; Jasmand et al., 2012; Mom et al., 2009). The current study adds to this understanding by empirically examining the cognitive resources that enable entrepreneurs to engage simultaneously in discovery and create approaches to opportunity perception.

\section{Cognitive resources effecting opportunity perception}

Building on the body of literature in cognitive psychology and social cognition theory, entrepreneurial cognition is defined as "the knowledge structures that people use to make assessments, judgments, or decisions involving opportunity evaluation, venture creation, and growth." (Mitchell et al., 2002, p. 97). The body of literature that has developed subsequently suggests cognitive resources explain how entrepreneurs perceive opportunity. In reviewing cognitive research in entrepreneurship, Grégoire et al. (2011) identify a number of cognitive resources that have been examined for entrepreneurs. Among these are selfefficacy, decision biases, prior knowledge, learning and experience. These authors recommend that future research examine antecedents of entrepreneurial cognition, especially cognitive resources that enable opportunity perception. While recent research has begun to offer a behavioral and cognitive explanation for opportunity discovery (Dyer et al., 2008; Neill et al., 2015), this study explores the ability of a set of cognitive resources (i.e. self-efficacy, representativeness bias, uncertainty intolerance, risk propensity, exploiting, exploring and experience) to distinguish between the approaches entrepreneurs take to opportunity perception.

Self-Efficacy. Self-efficacy is formed by an individual's collection of skills, experiences and assets and is defined as the individual's belief in his or her ability to perform and to achieve goals (Bandura, 1997; Kasouf et al., 2013). Entrepreneurial self-efficacy has the potential to influence entrepreneurial intent and the search and pursuit of opportunity (Drnovšek et al., 2010). Prior research shows a positive relationship between self-efficacy and the likelihood of becoming an entrepreneur (Cassar and Friedman, 2009; Chen et al., 1998; Zhao et al., 2005) and the pursuit of valuable opportunities (Ardichvili et al., 2003; Bayon et al., 2015). Krueger and Dickson (1994) find that self-efficacy increases perceptions of opportunity. Self-efficacy is a key ingredient in the ongoing pursuit of high-growth opportunity (Gundry and Welsch, 2001; Sweida and Reichard, 2013).

Representativeness bias. Representativeness bias is the tendency to overgeneralize from a few characteristics or observations. This concept is also referred to as a belief in the law of small numbers. Exposure to different, and possibly ambiguous, information offers entrepreneurs source material for market insights and may require significant and non-linear leaps in thinking based on a few facts or observations (Mitchell et al., 2007). Because entrepreneurs are unlikely to have access to or the resources for large-scale studies or market research, opportunity perception is often based on limited information (Busenitz and Barney, 1997; Keh et al., 2002; Murmann and Sardana, 2012). 
Uncertainty intolerance. Entrepreneurial actions are inherently uncertain (Markman and Baron, 2003; Hmieleski and Baron, 2009). Unlike risk, uncertainty cannot be estimated or predicted accurately (York and Venkataraman, 2010). Entrepreneurs have been found to have a high tolerance for ambiguity and are distinguished from non-entrepreneurs by their willingness to bear uncertainty (McMullen and Shepherd, 2006; York and Venkataraman, 2010). Tolerance for uncertainty enables the entrepreneur to innovate, to make decisions and to act in an ambiguous environment (Teoh and Foo, 1997; York and Venkataraman, 2010). An unwillingness to tolerate uncertainty prevents entrepreneurial action (McMullen and Shepherd, 2006). In fact, Fraser and Greene (2006) demonstrate that new entrepreneurs are more likely to exit when they experience high levels of uncertainty.

Risk propensity. Begley (1995) defines risk-taking propensity as the entrepreneur's willingness to take risks. Risk is a measurable unknown to which probabilities can be assigned (York and Venkataraman, 2010). Because risk is calculable, it can be mitigated by reward. The literature supports the notion that founding entrepreneurs are risk-takers who take chances and expect to profit handsomely as a reward for their risk bearing orientation (Begley, 1995; Stewart and Roth, 2001). By contrast, Brockhaus (1980) found that entrepreneurs tend to have only moderate risk-taking propensity; Palich and Bagby (1995) observed that entrepreneurs do not perceive themselves as being more predisposed to risk taking than non-entrepreneurs; and Miner and Raju (2004) report results from a metaanalysis indicating that entrepreneurs may be less likely to be risk prone. By examining motivations within a group of entrepreneurs, differences are noted with entrepreneurs seeking to pursue opportunity and a creative outlet being less risk averse than those motivated by necessity (Block et al., 2015). While researchers differ on their conclusions about entrepreneurs' risk-taking propensity, agreement exists on the importance of risk propensity in the context of entrepreneurship.

Exploiting. Exploiting emphasizes reliance on existing knowledge and alternatives (March, 1991). Entrepreneurs do rely on expertise and past experience (Baron, 2006; Sarasvathy and Dew, 2005). For example, they rely on prior knowledge of a market, technology, industry or customers as a basis for detecting new opportunities (Ardichvili et al., 2003; Baron and Ensley, 2006; Shane, 2000), leveraging what they know to "connect the dots" and identify if an opportunity is viable and distinctive (Santos et al., 2015). Prior knowledge and skills enable entrepreneurs to recognize opportunities that others overlook (Baron and Ensley, 2006; Neill et al., 2015; Ucbasaran et al., 2009); hence, reliance on existing knowledge is an important element of opportunity perception (Corbett, 2007; Shane, 2000).

Exploring. While exploiting existing knowledge and skills is important, overreliance on the familiar may make identifying new opportunity difficult (Ucbasaran et al., 2009). Entrepreneurs have to explore unknown domains, because opportunities often stem from new ideas, technologies, and markets (Dyer et al., 2008). Politis (2005) suggests that entrepreneurs need to deviate from the "tried-and-true" in order to learn something new, and Sigrist (1999) notes that entrepreneurs spend time and effort engaging in learning that advances and deepens their capabilities. In short, entrepreneurs seek to acquire new capabilities and information and transform them into entrepreneurial opportunity (Corbett, 2007). In founding new ventures, the entrepreneur may be called upon to learn new knowledge and skills whether to discover or to create opportunity.

Experience. Prior research has examined either the effects of experience on firm performance or differences between novice and repeat entrepreneurs (Sarasvathy et al., 2013; Westhead, Ucbasaran and Wright, 2005; Westhead, Ucbasaran, Wright and Binks, 2005; Zhang, 2011). Research examining the role of experience on opportunity perception for habitual and acquirer entrepreneurs has demonstrated that experienced entrepreneurs are more likely to perceive opportunity (Ucbasaran et al., 2003). Subsequent research also found that experienced 
entrepreneurs are more likely to discover and to create opportunity (Dew et al., 2009; Politis, 2008); however, no difference between experienced and novice entrepreneurs was found with respect to the tendency to draw conclusions from limited information (Dew et al., 2009).

\section{Approach to opportunity perception and growth expectations}

Growth expectation is the entrepreneur's belief about the future development of a new venture. Prior research has demonstrated that high-growth-oriented entrepreneurs differ in experience, motivations, risk propensity, strategic growth intentions and perceived success factors from low-growth entrepreneurs (Gundry and Welsch, 2001; Miner and Raju, 2004; Morris et al., 2006; Siegel et al., 1993). Evidence also indicates that high-growth-oriented entrepreneurs exhibit high levels of practical, analytical and creative intelligence, which motivates entrepreneurial behavior (Baum and Bird, 2010); however, prior research has not considered that the approach to opportunity perception may influence the entrepreneur's growth expectations. The mode applied to opportunity perception will influence where she believes her business will be relative to other firms in the industry after several years of operation (Figure 1).

\section{Methods}

Survey data collection

Data were gathered from 173 women who had previously sought one-time investment funding to start or sustain a new business from a group of investors focused on high-growth opportunities. The investment group actively sought to support women entrepreneurs in firms less than five years old with a credible plan and an innovative product or service that addressed a very sizable market in a scalable way. Firms of this age are classified as new ventures (Bantel, 1998; Zahra et al., 2000) and are in an early stage of development that focuses on conceptualization and commercialization (Hanks et al., 1993; Kazanjian, 1988). Private investor financing is of critical importance at this stage (Maxwell et al., 2011). In addition to capital infusion, early stage investors provide support through expertise and resource connections (Dutta and Folta, 2016; Ehrlich et al., 1994).

To be included in the study, respondents had to have met one or more of the following conditions: founding member, ownership share of at least 10 percent, senior (c-suite) manager, or board member. Given these requirements, eight respondents were removed from the study,

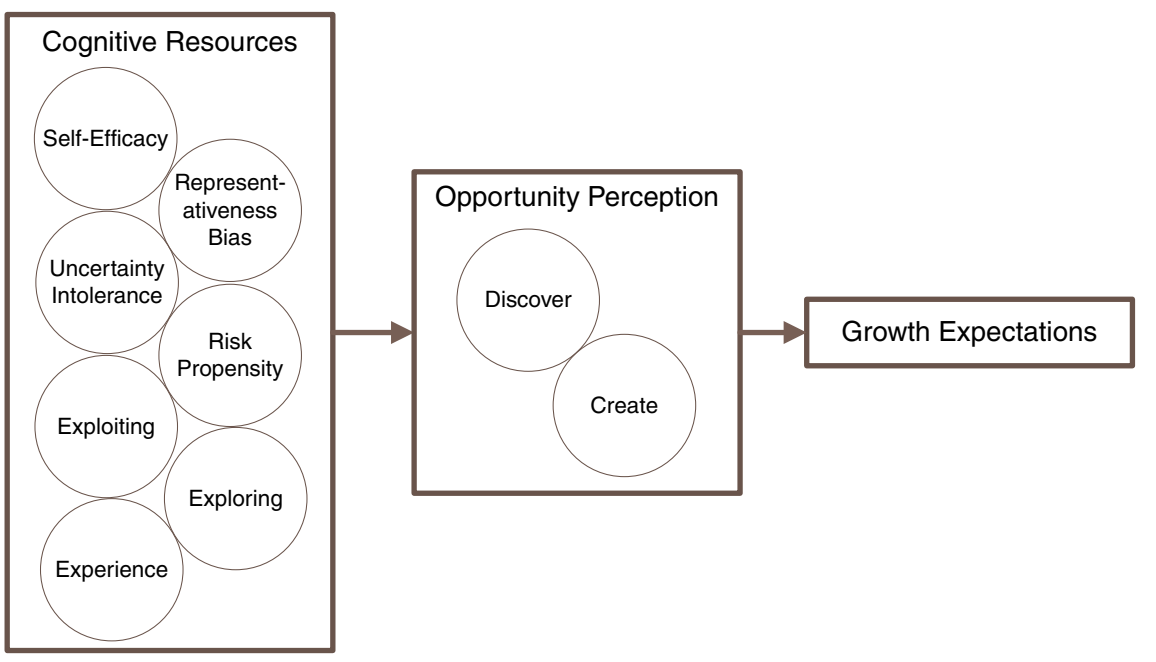

Figure 1.

Model of cognitive resources, opportunity perception and growth expectations 
leaving 165 usable responses. The remaining respondents were firm founders (93 percent) with over ten years of work experience. On average, respondents had been highly involved in two new business ventures prior to the most recent. A majority of respondents (66 percent) were married; 52 percent had children; and 57 percent had attained a graduate or professional degree. Respondents also represented a broad mix of industries: software/internet (21 percent), healthcare/medical (15 percent), manufacturing (14 percent), biotechnology (10 percent), and the remaining 40 percent distributed across a range of other industries.

\section{Identifying approaches to opportunity perception}

To determine approaches to opportunity perception, the summed items of the discover and create scales were input into a cluster analysis. The clustering variables were standardized prior to analysis. A hierarchical procedure, using Ward's method, was employed to determine the number of groups based on the degree of similarity. Determining the number of clusters was based on the agglomeration coefficient, which allows the researcher to assess the distance between clusters at each successive step (Hair et al., 2010). A large increase indicates the formation of a heterogeneous combination. K-means clustering was used to determine the final cluster membership, as this technique has proven robust in producing distinct, non-overlapping clusters (Milligan and Cooper, 1987).

\section{Discriminating between approaches to opportunity perception}

Multiple discriminant analysis was chosen as the goal was to identify groups (dependent variable) by explaining the bases for group membership using a set of metric independent variables; i.e., cognitive resources. The technique produces a set of discriminant functions based on the number of groups with each function representing a variate of independent variables that best discriminates one group from the others (Hair et al., 2010). A step-wise approach was chosen to allow for the most parsimonious set of maximally discriminating variables with each variable entering the variate only if providing unique and significant discriminatory power beyond that already accounting for in the variate. For this study, each function identified the cognitive resources associated with one group while indicating the unique contribution that each resource offers to members within that group.

\section{Results}

\section{Measurement results}

The source and the content of the eight scales used are listed in Table I. All items were assessed using a seven-point agree/disagree scale. Unidimensionality was first assessed using exploratory factor and scale item analyses based on the following criteria: factor loadings of at least 0.50 ; item-to-total correlations of at least 0.35 ; average inter-item correlations of at least 0.15; and Cronbach's $\alpha$ of at least 0.70 (Netemeyer et al., 2003). The measures were further subjected to confirmatory factor analysis with all eight constructs modeled as first-order factors in LISREL 8.8 using the covariance matrix as input. This approach allowed for an examination of both loadings and measurement error to identify candidates for removal. Based on this procedure, three self-efficacy items were removed.

Fit statistics and internal consistency coefficients were used to assess the reliability, model fit, and discriminant validity of the measures. The results indicated that the estimated measurement model adequately represented the observed input matrices, with a $\chi^{2}$ of $1,094.45$ with 751 degrees of freedom (df), a standardized root mean square residual of 0.08 , and comparative fit index of 0.89 . To determine that each measure was empirically distinct, discriminant validity was assessed and supported in all cases, as the square of the parameter estimate $(\phi)$ between each pair of constructs was less than the mean of the pair's average variance extracted estimates. Table II presents the internal consistency estimates and descriptive statistics for the study measures. 


\begin{tabular}{|c|c|}
\hline Measure & Scale items \\
\hline Discover $^{\mathrm{a}}$ & $\begin{array}{l}\text { I discover opportunities that others do not see } \\
\text { Opportunities are already formed and awaiting discovery by my alertness } \\
\text { Opportunities result from market or industry changes that I notice } \\
\text { To discover opportunities, I must systematically scan the environment } \\
\text { I believe external shocks form opportunities } \\
\text { Opportunities exist as objective phenomena just waiting for me to discover them }\end{array}$ \\
\hline Create $^{\mathrm{b}}$ & $\begin{array}{l}\text { I create the future that I seek } \\
\text { Opportunities emerge as the results of my actions } \\
\text { Opportunities are the outcome of my efforts and actions } \\
\text { I believe that opportunities are created, rather than discovered } \\
\text { Opportunities are created by my actions and reactions } \\
\text { I am an integral part of opportunity emergence as I invent what I believe to be viable }\end{array}$ \\
\hline Self-efficacy ${ }^{c}$ & $\begin{array}{l}\text { I will be able to achieve most of the goals that I have set for myself } \\
\text { When facing difficult tasks, I am certain that I will accomplish them } \\
\text { In general, I think that I can obtain outcomes that are important to me } \\
\text { I believe I can succeed at most any endeavor to which I set my mind } \\
\text { I will be able to successfully overcome many challenges }\end{array}$ \\
\hline $\begin{array}{l}\text { Representativeness } \\
\text { bias }^{\mathrm{a}}\end{array}$ & $\begin{array}{l}\text { I can recognize opportunities by observing just a small number of cases } \\
\text { I only need a few observations to have confidence in my decisions } \\
\text { If a few potential buyers like an idea, it's a valid opportunity } \\
\text { I do not require a lot of data to identify a marketable opportunity } \\
\text { I am able to recognize opportunities from a few direct experiences }\end{array}$ \\
\hline $\begin{array}{l}\text { Uncertainty } \\
\text { intolerance }\end{array}$ & $\begin{array}{l}\text { When it's time to act, uncertainty paralyses me } \\
\text { When I am uncertain, I cannot go forward } \\
\text { When I am uncertain, I cannot function very well } \\
\text { The smallest doubt can stop me from acting }\end{array}$ \\
\hline Risk propensity & $\begin{array}{l}\text { I am willing to take a big risk in order to realize higher gains } \\
\text { I like taking big risks } \\
\text { I choose alternatives with less chance for success and higher rewards } \\
\text { I choose a strategy that offers higher rewards but has a lower probability of success } \\
\text { I believe that higher risks are worth taking for higher rewards } \\
\text { I like to take chances, although I may fail } \\
\text { To earn greater rewards, I am willing to take higher risks }\end{array}$ \\
\hline Exploiting $^{\mathrm{a}}$ & $\begin{array}{l}\text { I would rather work with familiar routines } \\
\text { Given a choice, I stick to what I know best } \\
\text { I like to work with proven ideas } \\
\text { I think it is best to work with what you know }\end{array}$ \\
\hline Exploring $^{\mathrm{a}}$ & $\begin{array}{l}\text { My preference is to develop new knowledge and skills } \\
\text { I like to develop original ideas } \\
\text { I like to experiment with new approaches } \\
\text { I believe it is important to develop new knowledge and skills }\end{array}$ \\
\hline
\end{tabular}

Table I.

Measurement scale items

\section{Classification results}

Based on Ward's method results, the agglomeration coefficient indicated a rather large percentage increase going from three to two clusters signaling the formation of a heterogeneous combination. As such, the three-cluster solution was selected for subsequent analysis using the K-means approach. The standardized mean values for the two groups representing the discover and create approaches to opportunity perception are reported in Table III. The one-way analysis of variance results indicate that the cluster analysis succeeded in generating three distinct groups with an overall Wilk's $\lambda$ statistic of $0.15(F=144.52 ; \mathrm{df}=4,362 ; p<0.01)$. These results are summarized in Table III. 


\begin{tabular}{lcccc} 
Measure & Composite reliability & Average variance extracted & Mean & SD \\
\hline Discover & 0.72 & 0.30 & 6.55 & 0.48 \\
Create & 0.78 & 0.38 & 5.68 & 0.80 \\
Self-efficacy & 0.88 & 0.59 & 6.40 & 0.65 \\
Representativeness bias & 0.83 & 0.50 & 4.60 & 1.25 \\
Uncertainty intolerance & 0.89 & 0.67 & 1.60 & 1.00 \\
Risk propensity & 0.84 & 0.45 & 5.39 & 0.95 \\
Exploiting & 0.84 & 0.57 & 3.50 & 1.35 \\
Exploring & 0.78 & 0.47 & 6.60 & 0.60 \\
Experience & & & & \\
Work & - & - & 15.45 & 8.70 \\
Administrative & - & - & 10.74 & 8.33
\end{tabular}

Table II. Internal consistency and descriptive statistics

Note: All scales assessed using a seven-point agree/disagree scale, except for experience which is in years

\begin{tabular}{|c|c|c|c|c|}
\hline Dependent variable & Wilk's $\lambda$ & $F$-value & $\eta^{2}$ & Significant contrasts ${ }^{\mathrm{a}}$ \\
\hline Multivariate & 0.15 & $144.52^{*}$ & - & \\
\hline \multicolumn{5}{|l|}{ Univariate } \\
\hline Create & - & $173.59 *$ & 0.66 & $1-2,1-3,2-3$ \\
\hline Discover & - & $134.05^{*}$ & 0.60 & $1-2,1-3,2-3$ \\
\hline \multicolumn{5}{|c|}{ Standardized means and $S D$} \\
\hline Cognitive approach & $\begin{array}{l}\text { Cluster 1: } \\
\text { discovery }\end{array}$ & $\begin{array}{l}\text { Cluster 2: } \\
\text { creation }\end{array}$ & $\begin{array}{c}\text { Cluster 3: } \\
\text { ambidextrous }\end{array}$ & \\
\hline Create & $-1.58(0.63)$ & $0.14(0.68)$ & $0.52(0.53)$ & \\
\hline Discover & $-0.29(0.90)$ & $-1.13(0.62)$ & $0.67(0.52)$ & \\
\hline Percentage of sample & 20 & 26 & 54 & \\
\hline \multicolumn{5}{|c|}{ Notes: ${ }^{\mathrm{a}} 1=$ discovery, $2=$ creation, $3=$ ambidextrous. ${ }^{*} p<0.05$} \\
\hline
\end{tabular}

The three clusters represent three different entrepreneurial approaches to opportunity perception. Cluster one represents 20 percent of the sample. The mean values indicate that this group relies more on discovery and has the lowest tendency to employ a creation approach. Cluster two (26 percent of sample) reports greater reliance on creation and exhibits the lowest degree of discovery; as such, this group is labeled creation. The third group (54 percent of sample) emphasizes both discover and create, exhibiting a more ambidextrous approach to opportunity perception.

\section{Discriminating approaches to opportunity perception}

A discriminant analysis was performed to determine the relationship between the cognitive resources and the three approaches to opportunity perception. Cluster membership was the dependent variable, and the seven cognitive resources were the independent variables. To identify a parsimonious set of discriminating variables, a step-wise estimation procedure was used to derive the discriminant functions (Hair et al., 2010). This approach selects variables that maximize the discrimination between the most similar groups and continues for each variable that contributes additional significant discrimination. Table IV summarizes the multiple discriminant analysis results, which indicates a two-function solution based on five discriminating variables (i.e. self-efficacy, representativeness bias, exploit, explore and years of administrative experience). Table V provides standardized canonical coefficients, rotated structure matrix and mean values of the discriminating variables for each group. 
To validate the discriminant results, hit ratios were calculated using the analysis and a holdout sample of 20 additional women entrepreneurs not used in the initial model estimation. The classification accuracy based on the percentage correctly classified of the analysis sample is 58.10 percent for the analysis sample and 72.70 percent for the holdout sample. Both hit ratios compare favorably to a proportional chance criterion of 39.55 percent - exceeding this threshold value by more than 25 percent. As an additional statistical test for discriminatory power, Press's $Q$ is calculated as 42.66, which exceeds the critical value of 6.63 at a significance level of 0.01 . These results, along with the significant Wilk's $\lambda$ results, provide support for the relationship between the cognitive resources and the three approaches to opportunity perception.

\section{Testing the effect of approaches to opportunity perception on growth expectations}

To examine the relationship between the three approaches to opportunity perception and growth expectations, a multivariate analysis of variance was conducted. Results are presented in Table VI. The overall Wilk's $\lambda$ statistic was 0.85 ( $F=1.70 ;$ df16,320; $p<0.05$ ). The univariate $F$ tests and the corresponding significant contrasts indicate significant differences for growth expectations based on cognitive approach.

Overall, the results suggest that the ambidextrous approach had higher expectations on the following growth indications: partner network, geographic reach, market share, and employment growth. This ambidextrous approach also had higher growth expectations than the discovery approach for capital investment and revenue growth, and for the creation approach for innovative products. Further analysis provides some support that discoverytypes are more likely motivated to seek a lifestyle business, while creation- and ambidextroustypes initially seek to grow to IPO size or be acquired $\left(\chi^{2}=8.50 ; \mathrm{df}=4 ; p<0.10\right)$. While less

\begin{tabular}{lcc}
\hline Statistic & Function 1 & Function 2 \\
\hline Eigenvalue & 0.18 & 0.08 \\
Percent of common variance & 69.8 & 30.2 \\
Canonical correlation & 0.39 & 0.27 \\
Wilk's $\lambda$ & 0.79 & 0.93 \\
$\chi^{2}$ (df) & $35.56(10)^{*}$ & $11.07(4)^{*}$
\end{tabular}

Table IV. Discriminant analysis results

Note: $* p<0.05$

\begin{tabular}{|c|c|c|c|c|c|c|c|c|}
\hline \multirow[b]{2}{*}{ Discriminating variable } & \multicolumn{2}{|c|}{$\begin{array}{c}\text { Standardized } \\
\text { canonical coefficients }\end{array}$} & \multicolumn{2}{|c|}{$\begin{array}{c}\text { Rotated structure } \\
\text { matrix }\end{array}$} & \multicolumn{3}{|c|}{ Mean values by cognitive approach } & \\
\hline & 1 & 2 & 1 & 2 & Discovery & Creation & Ambidextrous & \\
\hline Self-efficacy & 0.38 & -0.99 & 0.56 & -0.80 & 6.18 & 6.42 & 6.62 & \\
\hline Representativeness bias & 0.40 & 0.34 & 0.35 & 0.19 & 4.68 & 4.36 & 4.80 & \\
\hline Uncertainty intolerance $^{a}$ & - & - & -0.17 & 0.18 & 1.71 & 1.44 & 1.64 & \\
\hline Risk propensity ${ }^{\mathrm{a}}$ & - & - & 0.13 & 0.03 & 5.21 & 5.18 & 5.60 & \\
\hline Exploit & 0.55 & 0.24 & 0.36 & 0.10 & 3.87 & 3.65 & 4.07 & \\
\hline Explore & 0.52 & 0.52 & 0.54 & 0.16 & 6.57 & 6.39 & 6.71 & \\
\hline Work experience $^{a}$ & - & - & 0.29 & 0.14 & 15.55 & 13.64 & 16.32 & Table V. \\
\hline $\begin{array}{l}\text { Administrative } \\
\text { experience }\end{array}$ & 0.47 & 0.20 & 0.35 & 0.20 & 10.95 & 8.77 & 11.77 & $\begin{array}{l}\text { Canonical coefficients, } \\
\text { structure matrix and }\end{array}$ \\
\hline Note: ${ }^{\mathrm{a}}$ Variable not usec & $\mathrm{d}$ in the anc & lysis & & & & & & mean values \\
\hline
\end{tabular}




\begin{tabular}{|c|c|c|c|c|}
\hline Dependent variable & Wilk's $\lambda$ & $F$-value & $\eta^{2}$ & Significant contrasts ${ }^{\mathrm{a}}$ \\
\hline Multivariate & 0.85 & $1.70^{*}$ & - & \\
\hline \multicolumn{5}{|l|}{ Univariate } \\
\hline Capital investment & - & $2.52 * *$ & 0.03 & $1-3$ \\
\hline Partner network & - & $4.42 *$ & 0.05 & $1-3,2-3$ \\
\hline Geographic reach & - & $5.85^{*}$ & 0.07 & $1-3,2-3$ \\
\hline Market share & - & $5.32 *$ & 0.06 & $1-3,2-3$ \\
\hline Revenue growth & - & $2.11^{*}$ & 0.03 & $1-3$ \\
\hline Employment growth & - & $1.91^{* *}$ & 0.02 & $1-2,1-3$ \\
\hline Intellectual property & - & 0.88 & 0.01 & - \\
\hline Innovative products & - & $2.13^{*}$ & 0.03 & $2-3$ \\
\hline \multicolumn{5}{|l|}{ Means and SD } \\
\hline Growth expectation & Cluster 1: & Cluster 2: & Cluster 3: & \\
\hline indicator & discovery & creation & ambidextrous & \\
\hline Capital investment & 4.17 & 4.66 & 5.00 & \\
\hline Partner network & 5.03 & 5.14 & 5.61 & \\
\hline Geographic reach & 4.67 & 4.72 & 5.40 & \\
\hline Market share & 4.86 & 4.87 & 5.52 & \\
\hline Revenue growth & 5.34 & 5.43 & 5.75 & \\
\hline Employment growth & 4.61 & 5.26 & 5.20 & \\
\hline Intellectual property & 5.37 & 5.04 & 5.21 & \\
\hline Innovative products & 5.89 & 5.47 & 5.78 & \\
\hline
\end{tabular}

Table VI.

Multivariate and univariate analysis of variance results
Notes: Each indicator assessed on a seven-point scale comparing growth expectations after the first several years of operation with other firms in the industry. ${ }^{a} 1=$ discovery, $2=$ creation, $3=$ ambidextrous. ${ }^{*} p<0.05$; $* * p<0.10$

than ten percent of the sample of entrepreneurs in high-growth new ventures were pursuing a lifestyle business, half of these were discovery-types though this group represents only 20 percent of respondents.

\section{Discussion}

In addressing the first research question on the tendency for entrepreneurs in high-growth new ventures to engage in one, the other, or both approaches to opportunity perception, the results suggest that about a fifth of respondents rely more on a discovery approach believing that opportunity exists as an independent phenomenon. Another quarter of respondents tend to rely more on a creation approach where opportunity forms based on the actions and interactions of the entrepreneur. The findings also reveal that a majority of entrepreneurs in high-growth new ventures engage in both the discovery and creation of opportunity. This ambidextrous group sees opportunity as emerging from both external sources as well as by their own doing. Thus, for these entrepreneurs, opportunity may form exogenously through market conditions detected by the entrepreneur, endogenously through actions of the entrepreneur, or both exogenously and endogenously through a process of recognition and development. This insight responds to the call for empirical support to add to the theoretical understanding of the opportunity construct (Dimov, 2011; Welter and Alvarez, 2015).

By revealing cognitive resources that distinguish the path to opportunity perception, the results address the second research question and offer important implications on the role of entrepreneurial cognition in empirically determining opportunity types. Entrepreneurs who rely on discovery and ambidextrous approaches to opportunity perception depend on a number of cognitive resources. The entrepreneurs who perceive an opportunity as exogenous are distinguished by having more prior managerial experience, exploring the unknown while exploiting the known, and drawing conclusions on the basis of a small 
number of observations. These entrepreneurs can rely on their experience, use what they know, learn what they need to know and take the leap based on limited external cues - to discover an idea that others overlooked and do something about it. Opportunity creation could be described as an almost naïve approach. The entrepreneurs who perceive opportunity as forming by their own interactions are distinguished by their lower levels of experience, reliance on known parameters, acquisition of new knowledge and skills, or weak signals; however, individuals comprising this group do exhibit greater belief in their own capabilities to succeed. In combining discovery with creation, the entrepreneurs comprising the ambidextrous group are the most likely to leverage experience, learning, and cognitive leaps. They are also highly confident in their capacity to succeed.

In examining how cognitive resources distinguish between each approach to opportunity perception, both interesting and unexpected findings emerge in relation to the extant literature. First, entrepreneurs comprising the opportunity creation group score lower on the exploit and explore scales than entrepreneurs comprising the discover cluster. These results are surprising and contrary to what might be expected. Opportunity creation would seem to require venturing into an unknown space and to be predicated on experimentation and the development of new knowledge and skills (Dyer et al., 2009), as well as on the ability to use the means at one's disposal (Sarasvathy and Dew, 2005). For the entrepreneurs in the opportunity creation group, the enactment of opportunity creation appears to be based on sheer will, rather than on learning and a preference for developing new knowledge and skills.

Second, entrepreneurs in the creation group score lower on representativeness bias than the entrepreneurs in the discovery group. Opportunity creation is about connecting the dots and associational thinking, whereas opportunity discovery is predicated on a search for and an analysis of all possible information. Consequently, one might expect entrepreneurs in the discover cluster to seek and to analyze information more aggressively, and to rely less on a heuristic, such as representativeness bias. The results suggest otherwise.

Third, the create cluster contains entrepreneurs who reported less managerial or administrative experience than the entrepreneurs in the discover cluster. Dyer et al. (2008) highlight the extent and breadth of experience required for opportunity creation. Additionally, Dew et al. (2009) found that experts identified more new markets than novices; therefore, one might expect entrepreneurs in the creation group to have more experience than entrepreneurs in the discovery group.

Fourth, reported scores on self-efficacy across all three clusters of entrepreneurs are consistent with what one might expect - discoverers report the lowest, ambidextrous entrepreneurs report the highest, and creators report self-efficacy scores between the two other groups. Opportunity creation is predicated on imagined possibilities, experimentation and learning from failures, and using one's skills and capabilities to bring an imagined future into being (Sarasvathy and Dew, 2005). The confidence to act on imagined possibilities requires high levels of self-efficacy, which is evident in the creation and ambidextrous groups.

Finally, entrepreneurs comprising the ambidextrous group report higher scores across all cognitive factors. Alvarez et al. (2013) note that ambidextrous entrepreneurs must be comfortable with decision-making that relies on data collection and analysis, as well as decision-making that relies on iteration, induction and intuition. The findings identify a cluster of entrepreneurs who rely on prior information and experience, as well as venturing into unknown space where new knowledge and skills develop and associations are unformed. These individuals pursue and resolve competing discover and create approaches to opportunity perception. Based on experience, learning, and a confidence in one's ability to succeed, the ambidextrous entrepreneur benefits from the inherent contradictions and tensions that exist between discover and create. Ambidextrous entrepreneurs engage in contradictory but mutually enabling approaches: one that is systematic and purposeful 
(discovery) and the other that enables them to create what they believe to be viable based on experimentation, learning and leveraging the resources at their disposal.

In addressing the third research question on how the entrepreneur's approach to opportunity perception influences new venture growth expectations, the results indicate that the ambidextrous group held the highest growth expectations. While the ambidextrous and discovery groups share common cognitive resources, these two groups were particularly different in terms of growth expectations with some evidence that the discover group had more moderate, lifestyle growth expectations. By contrast, the creation group differed from the ambidextrous group on multiple cognitive resources but shared similar capital investment and revenue growth expectations. Though the creation group was distinct in the cognitive underpinnings and perception of opportunity, this group's growth expectations were no different than the discovery group except for higher expectations of employment growth. While prior research has identified differences between the growth ambitions of entrepreneurs (Gundry and Welsch, 2001; Miner and Raju, 2004; Morris et al., 2006; Siegel et al., 1993), this study is the first to examine differences in entrepreneurs in high-growth new ventures and to link these differences to how to opportunity is perceived.

\section{Conclusions}

The findings offer insight on the cognitive origins of opportunity perception. The study validates distinct paths to opportunity perception and that entrepreneurs rely on different levels of cognitive resources in the path taken, which result in different growth expectations. Whether opportunity exists independent of the individual or as an artifact of the entrepreneur remains a debatable premise (Ramoglou and Zyglidopoulos, 2015). The current study focuses on what the entrepreneur perceives to be true as to the origin of opportunity and demonstrates that a set of cognitive resources - explore, exploit, self-efficacy, representativeness bias - distinguish how opportunity is perceived. Moreover, the study provides some insight into the role that experience performs in opportunity perception-with managerial experience performing a distinguishing role. Understanding the differences in how opportunity is perceived is important to the field of entrepreneurship and, by uncovering a set of cognitive resources that distinguish entrepreneurial perception, this study adds to the literature on entrepreneurial cognition.

The findings also have important implications to practice by bringing attention to the cognitive resources that influence the approach to opportunity perception. This knowledge can help to identify individuals with high-growth potential based on how opportunity is perceived. For aspiring and current entrepreneurs, the results of this study suggest that opportunity perception is based on the nature of the entrepreneur, i.e., her belief in her own abilities, her experience and expertise, and how she learns and draws conclusions. For practical purposes, the instruments could be used by investors to assess attributes of entrepreneurs that influence growth expectations. The women in this study demonstrated a link between the ability to discover and create opportunity and the vision to found high-growth business, thus providing positive role models and dismantling gender stereotypes associated with high-growth entrepreneurship.

For the first-time entrepreneur particularly, an awareness of cognitive styles may improve the chances of success by indicating not only the entrepreneur's strengths, but also potential vulnerable points. While this does not mean the entrepreneur needs to move away consciously from her dominant style, it may indicate that she should look for co-founders or key early employees who provide a balance and, in a sense, create an ambidextrous team. For example, York and Danes (2014), in a review of risk-reducing techniques for startups, suggest that founders conduct all customer development processes in pairs in order to reduce errors from representativeness bias. 
Policy makers, investors, and entrepreneurial educators can also benefit from an awareness of the impacts of cognitive resources on opportunity perception. With the rapid growth in private-sector, government, and university startup accelerators and incubators, interventions that support the creation of successful ventures and mitigate risk for investors and program sponsors are essential. Most programs supporting the creation of new ventures currently favor approaches that focus on customer development practices and highly iterative hypothesis testing, which might suit the create entrepreneur more closely. Through experimentation and learning, the create entrepreneur comes to "know" and is able to leverage available resources to create opportunity. On the other hand, the systematic and purposeful research, which is characteristic of the discover approach to opportunity perception, is also useful. Clearly new ventures need both, as entrepreneurs navigate an uncertain environment. Given the higher growth expectations of ambidextrous entrepreneurs, encouraging a dynamic ambidextrous approach to opportunity perception in these early stages of venture development may lead to better returns on the program sponsor's investment of both time and money.

This research also has implications for entrepreneurship educators, who can teach their students to engage in the contradictory, yet mutually enabling methods that the create and discover approaches to opportunity perception represent. Students can be taught to build skill sets that are characteristic of the create approach to opportunity perception (experiment, learn, leverage the resources at their disposal), as well as skill sets that are characteristic of the discover approach to opportunity perception (systematic, purposeful research and analysis).

\section{Limitations and opportunities for future research}

Several issues arise from this study with implications for further research. Grégoire $e t$ al. (2011) note the lack of clarity with respect to whether cognitive differences in entrepreneurs predate their entrepreneurial efforts and actions or whether the experience of entrepreneurship actually shapes cognitive differences. The current study - with its focus on experienced female entrepreneurs at a particular point in time-does not shed light on this research question. Distinguishing between factors that predate entrepreneurial action and factors that result from entrepreneurial action is a fruitful area for future research.

Focusing on context rather than cognitive resources, Zahra (2008) suggests that opportunity discovery is more apt to occur when technologies are emerging, the industry knowledge base is young, and the firm is specialized or focused on a particular emerging technology with a coherent strategic focus. Zahra (2008) further suggests that opportunity creation is more likely to occur when the firm is diversified technologically and seeking to deepen or broaden its skills and capabilities. In contrast, Sanz-Velasco (2006) finds that opportunity discovery occurs in situations of low risk and opportunity creation occurs in more uncertain situations. The current study does not examine the impact of context on opportunity perception; wherein, situational cues might trigger one form or both. The addition of context provides an avenue for future inquiry.

The current study examines a unique sample of women entrepreneurs in high-growth new ventures with over ten years of work experience and involvement in founding multiple businesses. A study of less experienced or "low growth" entrepreneurs may yield differences with regard to the role that cognitive resources play in opportunity discovery and opportunity creation, as might a study of male entrepreneurs. Likewise, a study examining managerial perceptions on corporate entrepreneurship (cf. Neill and York, 2012) might produce different implications. Hence, exploring the role that cognitive factors perform in opportunity perception in different populations may yield interesting comparisons.

This study is not without limitations, which should be acknowledged for their implications. Seeking parsimonious explanations of complex cognitive phenomenon 
introduces limitations and warrants caution in interpreting the results. Although the cognitive resources examined here are not exhaustive, the current study provides a starting point for future research. The effects tested are based on a cross-sectional survey design of a unique sample of high-growth-oriented entrepreneurs. A more diverse sample would serve to increase generalizability, while a case-based approach might isolate time-dependent and contextual effects. For example, future research might examine whether industry-level environmental dynamism is an important boundary condition to these results (e.g. Baron and Tang, 2011).

In summary, entrepreneurs vary in their cognitive approaches to opportunity perception, with some relying more on opportunity discovery, others on opportunity creation, and yet others who engage in both opportunity discovery and opportunity creation. The current study highlights the extent to which the cognitive resources of self-efficacy, decision biases, prior knowledge, learning, and experience influence opportunity discovery and opportunity creation in a sample of high-growth-oriented women entrepreneurs. Understanding the effects that these cognitive factors have on opportunity perception adds to the literature and provides direction for future research as well as professional development and educational strategies for current and aspiring entrepreneurs. While more research is needed, this study contributes to understanding the cognitive origins of opportunity.

\section{References}

Ahl, H. and Nelson, T. (2010), "Moving forward: institutional perspectives on gender and entrepreneurship", International Iournal of Gender and Entrepreneurship, Vol. 2 No. 1, pp. 5-9.

Alvarez, S.A. and Barney, J.B. (2007), "Discovery and creation: alternative theories of entrepreneurial action", Strategic Entrepreneurship Journal, Vol. 1 Nos 1-2, pp. 11-26.

Alvarez, S.A., Barney, J.B. and Anderson, P. (2013), "Forming and exploiting opportunities: the implications of discovery and creation processes for entrepreneurial and organizational research”, Organization Science, Vol. 24 No. 1, pp. 301-317.

Ardichvili, A., Cardozo, R. and Ray, S. (2003), "A theory of entrepreneurial opportunity identification and development", Journal of Business Venturing, Vol. 18 No. 1, pp. 105-123.

Baker, T. and Nelson, R.E. (2005), "Creating something from nothing: resource construction through entrepreneurial bricolage", Administrative Science Quarterly, Vol. 50 No. 3, pp. 329-366.

Bandura, A. (1997), Self-Efficacy: The Exercise of Control, W.H. Freeman \& Company, New York, NY.

Bantel, K.A. (1998), “Technology-based, 'Adolescent' firm configurations: strategy identification, context, and performance”, Journal of Business Venturing, Vol. 13 No. 3, pp. 205-230.

Baron, R.A. (2006), "Opportunity recognition as pattern recognition: how entrepreneurs 'connect the dots' to identify new business opportunities", Academy of Management Perspectives, Vol. 20 No. 1, pp. 104-119.

Baron, R.A. and Ensley, M.D. (2006), "Opportunity recognition as the detection of meaningful patterns: evidence from comparisons of novice and experienced entrepreneurs", Management Science, Vol. 52 No. 9, pp. 1331-1344.

Baron, R.A. and Tang, J. (2011), "The role of entrepreneurs in firm-level innovation: joint effects of positive affect, creativity, and environmental dynamism", Journal of Business Venturing, Vol. 26 No. 1, pp. 49-60.

Baum, J.R. and Bird, B.J. (2010), "The successful intelligence of high-growth entrepreneurs: links to new venture growth", Organization Science, Vol. 21 No. 2, pp. 397-412.

Bayon, M.C., Vaillant, Y. and Lafuente, E. (2015), "Initiating nascent entrepreneurial activities", International Iournal of Entrepreneurial Behaviour \& Research, Vol. 21 No. 1, pp. 27-49. 
Begley, T.M. (1995), "Using founder status, age of firm, and company growth rate as the basis for distinguishing entrepreneurs from managers of smaller businesses", Journal of Business Venturing, Vol. 10 No. 3, pp. 249-263.

Berenbaum, H., Bredemeier, K. and Thompson, R.J. (2008), "Intolerance of uncertainty: exploring its dimensionality and associations with need for cognitive closure, psychopathology, and personality", Journal of Anxiety Disorders, Vol. 22 No. 1, pp. 117-125.

Birkinshaw, J. and Gibson, C. (2004), "Building ambidexterity into an organization", MIT Sloan Management Review, Vol. 45 No. 4, pp. 47-55.

Block, J., Sandner, P. and Spiegel, F. (2015), "How do risk attitudes differ within the group of entrepreneurs? The role of motivation and procedural utility", Lournal of Small Business Management, Vol. 53 No. 1, pp. 183-206.

Brockhaus, R.H. (1980), "Risk taking propensity of entrepreneurs", Academy of Management Journal, Vol. 23 No. 3, pp. 509-520.

Busenitz, L.W. and Barney, J.B. (1997), "Differences between entrepreneurs and managers in large organizations: biases and heuristics in strategic decision-making", Iournal of Business Venturing, Vol. 12 No. 1, pp. 9-30.

Cassar, G. and Friedman, H. (2009), "Does self-efficacy affect entrepreneurial investment?", Strategic Entrepreneurship Journal, Vol. 3 No. 3, pp. 241-260.

Chandler, G.N., DeTienne, D.R., McKelvie, A. and Mumford, T.V. (2011), "Causation and effectuation processes: a validation study", Journal of Business Venturing, Vol. 26 No. 3, pp. 375-390.

Chen, C.C., Greene, P.G. and Crick, A. (1998), "Does entrepreneurial self-efficacy distinguish entrepreneurs from managers?", Lournal of Business Venturing, Vol. 13 No. 4, pp. 295-316.

Cohoon, J.M., Wadhwa, V. and Mitchell, L. (2010), "Are successful women entrepreneurs different from men?”, SSRN 1604653, Ewing Marion Kauffman Foundation, Kansas City, MO.

Coleman, S. and Robb, A. (2009), "A comparison of new firm financing by gender: evidence from the Kauffman Firm Survey Data", Small Business Economics, Vol. 33 No. 4, pp. 397-411.

Corbett, A.C. (2007), "Learning asymmetries and the discovery of entrepreneurial opportunities", Lournal of Business Venturing, Vol. 22 No. 1, pp. 97-181.

Dew, N., Read, S., Sarasvathy, S.D. and Wiltbank, R. (2009), "Effectual versus predictive logics in entrepreneurial decision-making: differences between experts and novices", Journal of Business Venturing, Vol. 24 No. 4, pp. 287-309.

Dimov, D. (2011), "Grappling with the unbearable elusiveness of entrepreneurial opportunities", Entrepreneurship Theory and Practice, Vol. 35 No. 1, pp. 57-81.

Drnovšek, M., Wincent, J. and Cardon, M.S. (2010), "Entrepreneurial self-efficacy and business start-up: developing a multi-dimensional definition", International Journal of Entrepreneurial Behaviour \& Research, Vol. 16 No. 4, pp. 329-348.

Dutta, D.K. and Thornhill, S. (2014), "Venture cognitive logics, entrepreneurial cognitive style, and growth intentions: a conceptual model and an exploratory field study", Entrepreneurship Research Journal, Vol. 4 No. 2, pp. 147-166.

Dutta, S. and Folta, T.B. (2016), "A comparison of the effect of angels and venture capitalists on innovation and value creation”, Lournal of Business Venturing, Vol. 31 No. 1, pp. 39-54.

Dyer, J.H., Gregersen, H.B. and Christensen, C. (2008), "Entrepreneur behaviors, opportunity recognition, and the origins of innovative ventures", Strategic Entrepreneurship Iournal, Vol. 2 No. 4, pp. 317-338.

Dyer, J.H., Gregersen, H.B. and Christensen, C. (2009), “The innovator's DNA", Harvard Business Review, Vol. 87 No. 12, pp. 61-67. 
Ehrlich, S.B., De Noble, A.F., Moore, T. and Weaver, R.R. (1994), "After the cash arrives: a comparative study of venture capital and private investor involvement in entrepreneurial firms", Journal of Business Venturing, Vol. 9 No. 1, pp. 67-82.

Fisher, G. (2012), "Effectuation, causation, and bricolage: a behavioral comparison of emerging theories in entrepreneurship research", Entrepreneurship Theory and Practice, Vol. 36 No. 5, pp. 1019-1051.

Floyd, S.W. and Lane, P.J. (2000), "Strategizing throughout the organization: managing role conflict in strategic renewal", Academy of Management Review, Vol. 25 No. 1, pp. 154-177.

Fraser, S. and Greene, F.J. (2006), "The effects of experience on entrepreneurial optimism and uncertainty", Economica, Vol. 73 No. 290, pp. 169-192.

Gibson, C.B. and Birkinshaw, J. (2004), "The antecedents, consequences, and mediating role of organizational ambidexterity", Academv of Management Iournal, Vol. 47 No. 2, pp. 209-226.

Greene, P.G., Hart, M.M., Gatewood, E.J., Brush, C.G. and Carter, N.M. (2003), "Women entrepreneurs: moving front and center: an overview of research and theory", Coleman White Paper Series, pp. 1-47.

Grégoire, D.A., Corbett, A.C. and McMullen, J.S. (2011), “The cognitive perspective in entrepreneurship: an agenda for future research", Lournal of Management Studies, Vol. 48 No. 6, pp. 1443-1477.

Gundry, L.K. and Welsch, H.P. (2001), "The ambitious entrepreneur: high growth strategies of womenowned enterprises", Journal of Business Venturing, Vol. 16 No. 5, pp. 453-470.

Hair, J.F., Black, B., Babin, B.J. and Anderson, R.E. (2010), Multivariate Data Analysis, Prentice Hall, Upper Saddle River, NJ

Hanks, S.H., Watson, C.J., Jansen, E. and Chandler, G.N. (1993), "Tightening the life-cycle construct: a taxonomic study of growth stage configurations in high-technology organizations", Entrepreneurship: Theory and Practice, Vol. 18 No. 2, pp. 5-30.

He, Z.L. and Wong, P.K. (2004), "Exploration vs exploitation: an empirical test of the ambidexterity hypothesis", Organization Science, Vol. 15 No. 4, pp. 481-494.

Hmieleski, K.M. and Baron, R.A. (2009), "Entrepreneurs' optimism and new venture performance: a social cognitive perspective", Academy of Management Journal, Vol. 5 No. 3, pp. $473-488$.

Jansen, J.J.P., Tempelaar, M.P., Van, den Bosch, F.A.J. and Volberda, H.W. (2009), "Structural differentiation and ambidexterity: the mediating role of integration mechanisms", Organization Science, Vol. 20 No. 4, pp. 797-811.

Jasmand, C., Blazevic, V. and de Ruyter, K. (2012), "Generating sales while providing service: a study of customer service representatives' ambidextrous behavior”, Journal of Marketing, Vol. 76 No. 1, pp. 20-37.

Jennings, J.E. and Brush, C.G. (2013), "Research on women entrepreneurs: challenges to (and from) the broader entrepreneurship literature?", Academy of Management Annals, Vol. 7 No. 1, pp. 663-715.

Junni, P., Sarala, R.M., Taras, V. and Tarba, S.Y. (2013), "Organizational ambidexterity and performance: a meta-analysis", Academv of Management Perspectives, Vol. 27 No. 4, pp. 299-312.

Kaish, S. and Gilad, B. (1991), "Characteristics of opportunities search of entrepreneurs versus executives: sources, interests, general alertness”, Lournal of Business Venturing, Vol. 6 No. 1, pp. 45-61.

Kasouf, C.J., Morrish, S.C. and Miles, M.P. (2013), "The moderating role of explanatory style between experience and entrepreneurial self-efficacy", International Entrepreneurship and Management Iournal, Vol. 11 No. 1, pp. 1-17.

Kauffman Foundation (2016), "Kauffman compilation: research on gender and entrepreneurship", Ewing Marion Kauffman Foundation, Kansas City, KS. 
Kazanjian, R.K. (1988), "Relation of dominant problems to stages of growth in technology-based new ventures", Academy of Management Journal, Vol. 31 No. 2, pp. 257-279.

Keh, H.T., Foo, M.D. and Lim, B.C. (2002), "Opportunity evaluation under risky conditions: the cognitive processes of entrepreneurs", Entrepreneurship Theory and Practice, Vol. 27 No. 2, pp. 125-148.

Kelly, D., Brush, C., Greene, P., Herrington, M., Ali, A. and Kew, P. (2015), "Special report: women's entrepreneurship", Global Entrepreneurship Monitor, London, available at: www. gemconsortium.org/report/49281 (accessed October 5, 2016).

Kirzner, I.M. (1973), Competition and Entrepreneurship, University of Chicago Press, Chicago, IL.

Klein, P.G. (2008), “Opportunity discovery, entrepreneurial action, and economic organization”, Strategic Entrepreneurship Journal, Vol. 2 No. 3, pp. 175-190.

Krueger, N. Jr and Dickson, P.R. (1994), "How believing in ourselves increases risk taking: perceived self-efficacy and opportunity recognition”, Decision Science, Vol. 25 No. 3, pp. 385-400.

Leyden, D.P. and Link, A.N. (2015), “Toward a theory of the entrepreneurial process”, Small Business Economics, Vol. 44 No. 3, pp. 475-484.

Lubatkin, M.H., Simsek, Z., Ling, Y. and Veiga, J.F. (2006), “Ambidexterity and performance in small- to medium-sized firms: the pivotal role of top management team behavioral integration", Journal of Management, Vol. 32 No. 5, pp. 646-672.

McMullen, J.S. and Shepherd, D.A. (2006), "Entrepreneurial action and the role of uncertainty in the theory of the entrepreneur", Academy of Management Review, Vol. 31 No. 1, pp. 132-152.

March, J.G. (1991), "Exploration and exploitation in organizational learning", Organization Science, Vol. 2 No. 1, pp. 71-87.

Markman, G.D. and Baron, R.A. (2003), "Person-entrepreneurship fit: why some people are more successful as entrepreneurs than others", Human Resource Management Review, Vol. 13 No. 2, pp. 281-301.

Maxwell, A.L., Jeffrey, S.A. and Lévesque, M. (2011), "Business angel early stage decision making”, Journal of Business Venturing, Vol. 26 No. 2, pp. 212-225.

Milligan, G.W. and Cooper, M.C. (1987), "Methodology review: clustering methods", Applied Psychological Measurement, Vol. 11 No. 4, pp. 329-354.

Miner, J.B. and Raju, N.S. (2004), "Risk propensity differences between managers and entrepreneurs and between low- and high-growth entrepreneurs: a reply in a more conservative vein", Lournal of Applied Psychology, Vol. 89 No. 1, pp. 3-13.

Mitchell, L. (2011), "Overcoming the gender gap: women entrepreneurs as economic drivers", Ewing Marion Kauffman Foundation, Kansas City, KS.

Mitchell, R.K., Mitchell, J.R. and Smith, J.B. (2008), "Inside opportunity formation: enterprise failure, cognition, and the creation of opportunities", Strategic Entrepreneurship Journal, Vol. 2 No. 3, pp. 225-242.

Mitchell, R.K., Busenitz, L., Lant, T., McDougall, P.P., Morse, E.A. and Smith, J.B. (2002), "Toward a theory of entrepreneurial cognition: rethinking the people side of entrepreneurship research", Entrepreneurship Theory and Practice, Vol. 27 No. 2, pp. 93-104.

Mitchell, R.K., Busenitz, L., Bird, B., Gaglio, C.M., McMullen, J.S., Morse, E.A. and Smith, J.B. (2007), "The central question in entrepreneurial cognition research", Entrepreneurship Theory and Practice, Vol. 31 No. 1, pp. 1-27.

Mom, T.J., Van Den Bosch, F.A. and Volberda, H.W. (2009), “Understanding variation in managers' ambidexterity: investigating direct and interaction effects of formal structural and personal coordination mechanisms", Organization Science, Vol. 20 No. 4, pp. 812-828.

Morris, M.H., Miyasaki, N.N., Watters, C.E. and Coombes, S.M. (2006), "The dilemma of growth: understanding venture size choices of women entrepreneurs", Lournal of Small Business Management, Vol. 44 No. 2, pp. 221-244. 
Murmann, J.P. and Sardana, D. (2012), "Successful entrepreneurs minimize risk", Australian Iournal of Management, Vol. 38 No. 1, pp. 191-215.

Neale, M.A. and Bazerman, M.H. (1991), Cognition and Rationality in Negotiation, Free Press, New York, NY.

Neill, S. and York, J.L. (2012), "The entrepreneurial perceptions of strategy makers: constructing an exploratory path in the pursuit of radical growth", Lournal of Business Research, Vol. 65 No. 7 , pp. 1003-1009.

Neill, S., Metcalf, L. and York, J. (2015), "Seeing what others miss: a study of women entrepreneurs in high-growth startups", Entrepreneurship Research Journal, Vol. 5 No. 4, pp. 293-322.

Netemeyer, R.G., Bearden, W.O. and Sharma, S. (2003), Scaling Procedures: Issues and Applications, Sage Publications, Thousand Oaks, CA.

Palich, L.E. and Bagby, D.R. (1995), "Using cognitive theory to explain entrepreneurial risk-taking: challenging conventional wisdom", Iournal of Business Venturing, Vol. 10 No. 6, pp. $425-438$.

Politis, D. (2005), “The process of entrepreneurial learning: a conceptual framework", Entrepreneurship Theory and Practice, Vol. 29 No. 4, pp. 399-424.

Politis, D. (2008), "Does prior start-up experience matter for entrepreneurs' learning? A comparison between novice and habitual entrepreneurs", Lournal of Small Business and Enterprise Development, Vol. 15 No. 3, pp. 472-489.

Raisch, S. and Birkinshaw, J. (2008), "Organizational ambidexterity: antecedents, outcomes, and moderators”, Lournal of Management, Vol. 34 No. 3, pp. 375-409.

Raisch, S., Birkinshaw, J., Probst, G. and Tushman, M.L. (2009), "Organizational ambidexterity: balancing exploitation and exploration for sustained performance", Organization Science, Vol. 20 No. 4, pp. 685-695.

Ramoglou, S. and Zyglidopoulos, S.C. (2015), "The constructivist view of entrepreneurial opportunities: a critical analysis", Small Business Economics, Vol. 44 No. 1, pp. 71-78.

Santos, S.C., Caetano, A., Baron, R. and Curral, L. (2015), "Prototype models of opportunity recognition and the decision to launch a new venture", International Iournal of Entrepreneurial Behaviour \& Research, Vol. 21 No. 4, pp. 510-538.

Sanz-Velasco, S. (2006), "Opportunity development as a learning process for entrepreneurs", International Journal of Entrepreneurial Behaviour \& Research, Vol. 12 No. 5, pp. 251-271.

Sarasvathy, S., Dew, N.V., Velamuri, S.R.S. and Venkataraman, S. (2010), "Three views of entrepreneurial opportunity", in Acs, Z.J. and Audretsch, D.B. (Eds), Handbook of Entrepreneurship Research, 2nd ed., Kluwer, Boston, MA, pp. 77-96.

Sarasvathy, S.D. (2001), "Causation and effectuation: toward a theoretical shift from economic inevitability to entrepreneurial contingency", Academv of Management Review, Vol. 26 No. 2, pp. 243-263.

Sarasvathy, S.D. and Dew, N. (2005), "Entrepreneurial logics for a technology of foolishness", Scandinavian Iournal of Management, Vol. 21 No. 4, pp. 385-406.

Sarasvathy, S.D., Menon, A.R. and Kuechle, G. (2013), "Failing firms and successful entrepreneurs: serial entrepreneurship as a temporal portfolio", Small Business Economics, Vol. 40 No. 2, pp. 417-434.

Shane, S. (2000), "Prior knowledge and the discovery of entrepreneurial opportunities", Organization Science, Vol. 11 No. 4, pp. 448-469.

Shane, S. (2008), The Illusions of Entrepreneurship: The Costly Myths that Entrepreneurs, Investors, and Policy Makers Live By, Yale University Press, New Haven, CT.

Shane, S. (2012), "Reflections on the 2010 AMR decade award: delivering on the promise of entrepreneurship as a field of research", Academy of Management Review, Vol. 37 No. 1, pp. 10-20.

Shane, S. and Venkataraman, S. (2000), "The promise of entrepreneurship as a field of research", Academy of Management Review, Vol. 25 No. 1, pp. 217-226. 
Shepherd, D.A., McMullen, J.S. and Jennings, P.D. (2007), "The formation of opportunity beliefs: overcoming ignorance and reducing doubt", Strategic Entrepreneurship Iournal, Vol. 1 Nos 1-2, pp. 75-95.

Siegel, R., Siegel, E. and Macmillan, I.C. (1993), "Characteristics distinguishing high-growth ventures", Journal of Business Venturing, Vol. 8 No. 2, pp. 169-180.

Sigrist, B. (1999), "Entrepreneurial opportunity recognition", a presentation at the Annual UIC/AMA symposium at Marketing/Entrepreneurship Interface, Sofia-Antipolis.

Simsek, Z., Heavey, C., Veiga, J.F. and Souder, D. (2009), "A typology for aligning organizational ambidexterity's conceptualizations, antecedents, and outcomes", Lournal of Management Studies, Vol. 46 No. 5, pp. 864-894.

Smith, W.K. and Tushman, M.L. (2005), "Managing strategic contradictions: a top management model for managing innovation streams", Organization Science, Vol. 16 No. 5, pp. 522-536.

Stewart, W.H. Jr and Roth, P.L. (2001), "Risk propensity differences between entrepreneurs and managers: a meta-analytic review", Journal of Applied Psvchology, Vol. 86 No. 1, pp. 145-153.

Sweida, G.L. and Reichard, R.J. (2013), "Gender stereotyping effects on entrepreneurial self-efficacy and high-growth entrepreneurial intention", Journal of Small Business and Enterprise Development, Vol. 20 No. 2, pp. 296-313.

Tang, J., Kacmar, K.M. and Busenitz, L. (2012), "Entrepreneurial alertness in the pursuit of new opportunities", Journal of Business Venturing, Vol. 27 No. 1, pp. 77-94.

Teoh, H.Y. and Foo, S.L. (1997), "Moderating effects of tolerance for ambiguity and risk-taking propensity on the role conflict-perceived performance relationship: evidence from singaporean entrepreneurs", Journal of Business Venturing, Vol. 12 No. 1, pp. 67-81.

Ucbasaran, D., Westhead, P. and Wright, M. (2009), "The extent and nature of opportunity identification by experienced entrepreneurs", Lournal of Business Venturing, Vol. 24 No. 2, pp. 99-115.

Ucbasaran, D., Westhead, P., Wright, M. and Binks, M. (2003), "Does entrepreneurial experience influence opportunity identification?", Journal of Private Equity, Vol. 7 No. 1, pp. 7-14.

Vaghely, I.P. and Julien, P.A. (2010), "Are opportunities recognized or constructed? An information perspective on entrepreneurial opportunity identification", Iournal of Business Venturing, Vol. 25 No. 1, pp. 73-86.

Volery, T., Mueller, S. and von Siemens, B. (2015), "Entrepreneur ambidexterity: a study of entrepreneur behaviours and competencies in growth-oriented small and medium-sized enterprises", International Small Business Journal, Vol. 33 No. 2, pp. 109-129.

Welter, C. and Alvarez, S. (2015), "The state of opportunities: clarifying the transitions between opportunity types", Management Decision, Vol. 53 No. 7, pp. 1398-1411.

Westhead, P., Ucbasaran, D. and Wright, M. (2005), "Experience and cognition do novice, serial and portfolio entrepreneurs differ?", International Small Business Iournal, Vol. 23 No. 1, pp. 72-98.

Westhead, P., Ucbasaran, D., Wright, M. and Binks, M. (2005), "Novice, serial and portfolio entrepreneur behaviour and contributions", Small Business Economics, Vol. 25 No. 2, pp. 109-132.

Wood, M.S. and McKinley, W. (2010), "The production of entrepreneurial opportunity: a constructivist perspective", Strategic Entrepreneurship Iournal, Vol. 4 No. 1, pp. 66-84.

York, J. and Danes, J.E. (2014), "Customer development, innovation, and decision-making biases in the lean startup”, Journal of Small Business Strategy, Vol. 24 No. 2, pp. 21-39.

York, J.G. and Venkataraman, S. (2010), "The entrepreneur-environment Nexus: uncertainty, innovation, and allocation", Journal of Business Venturing, Vol. 25 No. 5, pp. 449-463.

Zahra, S.A. (2008), "The virtuous cycle of discovery and creation of entrepreneurial opportunities", Strategic Entrepreneurship Iournal, Vol. 2 No. 3, pp. 243-257. 
Zahra, S.A., Ireland, R.D. and Hitt, M.A. (2000), "International expansion by new venture firms: international diversity, mode of market entry, technological learning, and performance", Academy of Management Journal, Vol. 43 No. 5, pp. 925-950.

Zhang, J. (2011), "The advantage of experienced start-up founders in venture capital acquisition: evidence from serial entrepreneurs", Small Business Economics, Vol. 36 No. 2, pp. 187-208.

Zhao, H., Seibert, S.E. and Hills, G.E. (2005), "The mediating role of self-efficacy in the development of entrepreneurial intentions", Lournal of Applied Psychology, Vol. 90 No. 6, pp. 1265-1272.

\section{Further reading}

Baron, R.A., Tang, J. and Hmieleski, K.M. (2011), “The downside of being 'up': entrepreneurs' dispositional positive affect and firm performance”, Strategic Entrepreneurship Iournal, Vol. 5 No. 2, pp. 101-119.

Chen, J. (2013), "Selection and serial entrepreneurs", Lournal of Economics \& Management Strategy, Vol. 22 No. 2, pp. 281-311.

McMullen, J.S. and Shepherd, D.A. (2003), "Extending the theory of the entrepreneur using a signal detection framework", Cognitive Approaches to Entrepreneurship Research, Emerald Group Publishing Limited, pp. 139-180.

Sarasvathy, S. (2008), Effectuation: Elements of Entrepreneurial Expertise, Edward Elgar Publishing Limited, Cheltenham.

\section{Corresponding author}

Stern Neill can be contacted at: sneill@calpoly.edu 